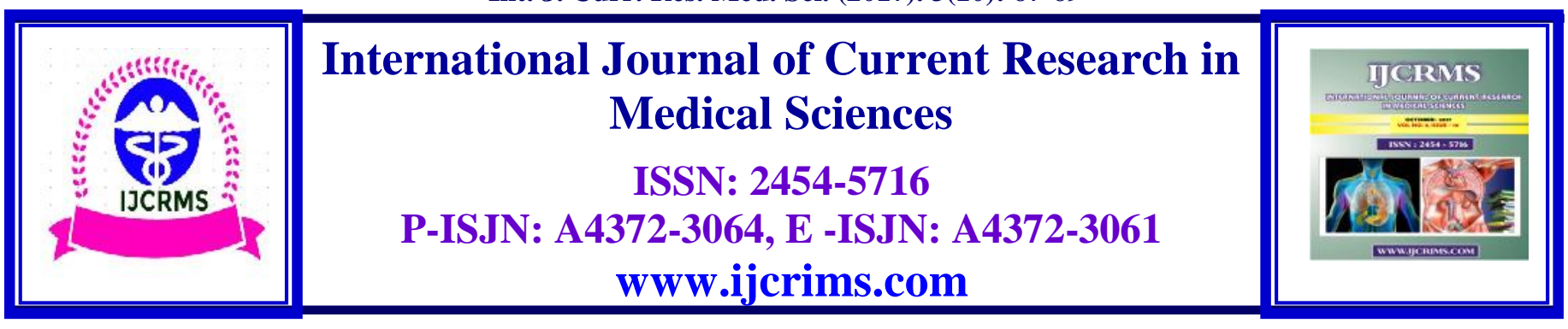

Case Report

Volume 3, Issue 10 -2017

DOI: http://dx.doi.org/10.22192/ijcrms.2017.03.10.011

\title{
Complete Type of Metopism in Adult Human Dry Skull - Anatomical Variation
}

\author{
B. Chandrakala ${ }^{1}$, G. Sumathy ${ }^{2} *$, S.Kanimozhi ${ }^{3}$, R.Sathish ${ }^{4}$ \\ ${ }^{1}$ Senior Lecturer, Dept. of Anatomy, Sree Balaji Dental College and Hospital, BIHER, Chennai. \\ ${ }^{2}$ Professor and Head, Dept. of Anatomy, Sree Balaji Dental College and Hospital, BIHER, \\ Chennai. \\ ${ }^{3}$ Lecturer, Dept. of Anatomy, Sri Sairam Siddha Medical College and Research Centre \\ ${ }^{4}$ Reader, Dept. of Sattam Sarntha Maruthuvamum Nanju Maruthuvamum, Sri Sairam Siddha \\ Medical College and Research Centre. \\ *Corresponding Author: G. Sumathy \\ Professor and Head, Dept. of Anatomy, Sree Balaji Dental College and Hospital, BIHER
}

Chennai.

\begin{abstract}
We have observed one adult human dry skull with a complete type of metopic suture in frontal bone extending from the nasion to bregma of the skull in the Department of Anatomy, Sree Balaji Dental College and Hospital, Chennai. Metopic suture was extended from nasion and fuses with the coronal suture near the bregma which was considered under the complete type of metopic suture as per previous literature. The incidence (5\%) of our case report is similar to the incidence of Punjabi Indians, yellow race and Mongolian population. Our case report helps the neurosurgeons before planning any frontal craniotomy and knowledge on anatomical variation of sutural bones would be useful to the anthropologists and forensic expects in medico - legal conditions.
\end{abstract}

Keywords: Bregma, Frontal bone, Metopic suture, Craniotomy, Anthropologist

\section{Introduction}

The frontal bone is an unpaired bone of the skull which ossifies in the fibrous membrane at 8th week of intrauterine life from two primary centers [1]. The frontal suture divides the two halves of the frontal bone in infants and children. It is also called as metopic sutures. The morphology of the metopic suture varies. Metopic suture extends from bregma to nasion is called as complete metopic suture or sutura frontalis persistens. The fusion of this metopic suture starts at the anterior fontanelle and terminates at the nasion [2, 3]. Metopic suture can be due to various causes such as abnormal growth of cranial bones, growth interruption, heredity, sexual, hormonal influence, atavism, cranial malformations, and hydrocephalus [4]. In some individuals this sutures may persist into adult which is referred as persistent metopic suture. Sometimes the metopic suture can be confused with supranasal sutures which are superior to glabella. 


\section{Case History}

We have utilized 25 human dry skulls of both the sexes from the Department of Anatomy to study the sutures of skull and their variations. We have observed one skull with complete type of metopism extending from the nasion to the bregma [Figure-1]. We have also observed the

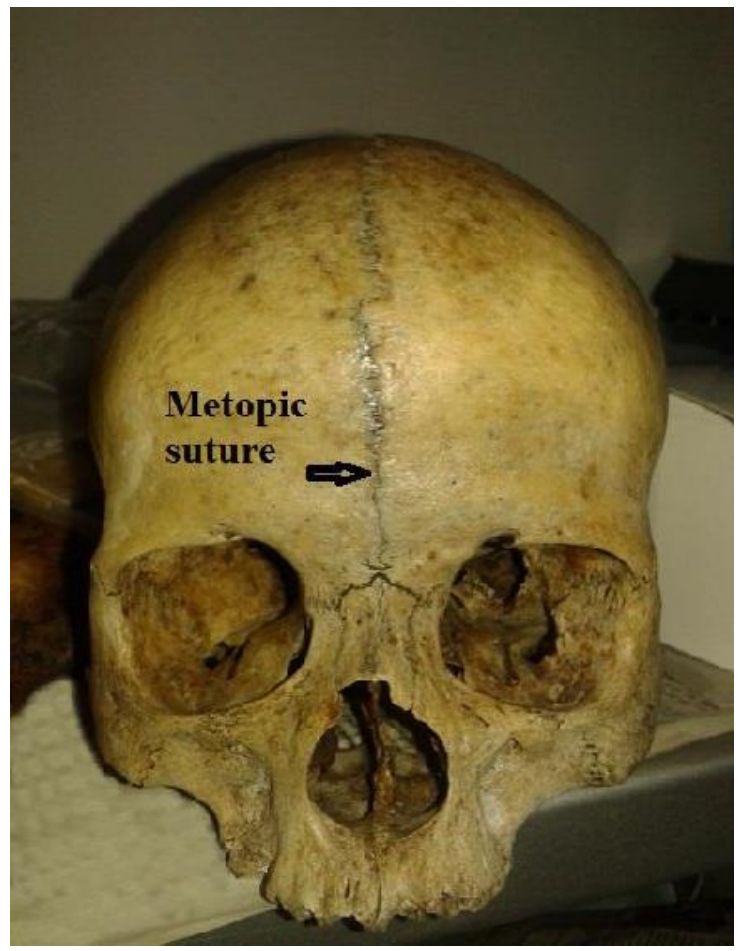

Figure -1: Adult dry skull with complete type of metopism extending from the Nasion to the Bregma (Metopic suture - Arrow)

\section{Discussion}

Metopism is found in $5.1 \%$ of Asians and $8.7 \%$ in European Caucasians. Sutural bones are very commonly found in the skull. Nearly $40 \%$ of skulls contain sutural bones in the vicinity of the lambdoid suture [5].Metopism was observed in $3.2 \%$ of the skulls, and incomplete metopic suture was present in $26.4 \%$ of the 125 adult skulls that were examined in south Indian population [6]. Bryce reports metopism is present in $5.1 \%$ of Mongolian subjects, $8.7 \%$ of European crania, $9.5 \%$ of Scottish skulls, $1.2 \%$ of Negroes and $1 \%$ of Australian skulls [3,7]. In our study, metopism was found in one skull out of 20 human dry skulls with an incidence of 5\% which similar sutured pattern of this metopic suture in its extent from the nasion to bregma. The metopic suture joining with the coronal suture is very close to the bregma [Figure-2]. According to the previous literatures we considered this metopic suture as complete metopism of human skull due to its extension from nasion to bregma of the skull.

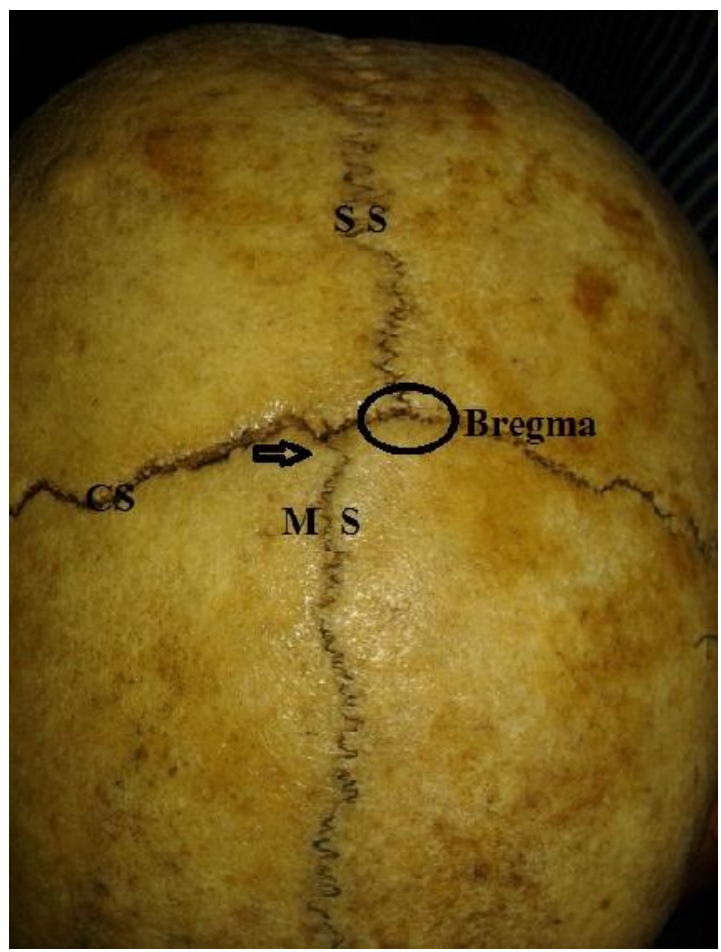

Figure -2: Metopic suture joining with the coronal suture very close to the bregma (M S - Metopic Suture, SS - Sagittal Suture)

to the incidence of Punjabi Indians, yellow race and Mongolian populations [8].The incidence of our report is lesser than the incidence of European, Scottish, Mangoloid population [9] and higher than the incidence reported in other races $[10,11]$. Caffey stated that metopic suture may persist up to the sixth year and even throughout life in about $10 \%$ of cases in dry skull studies [12].

\section{Conclusion}

It is important to know about the presence of metopic suture and the type of metopic suture because they can mislead in the diagnosis of fracture of frontal bone in medico legal cases 


\section{References}

1. Williams PL, Bannister LH, Berry MM, Collins P, Dyson M, Dussek JE, Ferguson MWJ, eds. Gray's Anatomy. 38th Ed., Baltimore, Churchil and Livingstone. 1995; 595.

2. Weinzweig J, Kirschner RE, Farley A, Reiss P, Hunter J, Whitaker LA, et al. Metopic synostosis: Defining the temporal sequence of normal suture fusion and differentiating it from synostosis on the basis of computed tomography images. Plast Reconstr Surg 2003; 112:1211-8.

3. Breathnach, A. S. (1958). Frazer's Anatomy ofthe Human Skeleton, 5th ed. London: Churchill.

4. Del Sol, M.; Binvignat, O.; Bolini, P. D. A. \& Prates, J. C. Metopismonoindividuobrasileiro. Rev. Paul. Med., 107(2):105-7, 1989.

5. Poonam Verma Seema, Anupama Mahajan. Human skull with complete metopic suture and multiple sutural bones at lambdoid suture - a case report.International Journal of Anatomical Variations (2014) 7: 7-9.

6. Hussain Saheb S, Mavishettar GF, Thomas ST, Prasanna LC. Incidence of metopic suture in adult south Indian skulls.J Biomed Sci Res 2010; 2:223-6.

7. Bryce, T.H. (1915). Osteology and Arthrology. In Quain's Elements of Anatomy, 11th ed., vol. 4, pt. I, p. 177.

8. Jit I and Shah MA. Incidence of frontal or metopic suture amongst Punjabi adults. Ind Med Gaz, 1948; 83:507.

9. Woo, Ju-Kong (1949). Racial and sexual differences in the frontal curvature and its relation to metopism. American Journal of Physical Anthropology 7, 215-226.

10. Ajmani, M. L.; Mittal, R. K. \& Jain, S. P. Incidence of the metopic suture in adult Nigerian Skulls. J. Anat., 137(1):177-83, 1983.

11. Das A.C., Saxena, R. C. \& Beg, M. A. Q. (1973).Incidence of metopic suture in U.P. subjects. Journal of the Anatomical Society of India 22,140 .

\begin{tabular}{|c|c|}
\hline \multicolumn{2}{|c|}{ Access this Article in Online } \\
\hline 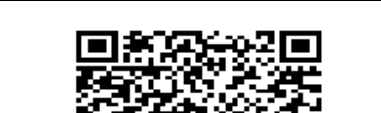 & $\begin{array}{l}\text { Website: } \\
\text { www.ijcrims.com }\end{array}$ \\
\hline 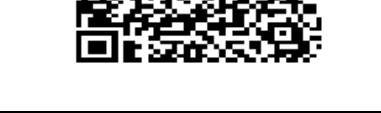 & \multirow[t]{2}{*}{$\begin{array}{l}\text { Subject: } \\
\text { Medical Sciences }\end{array}$} \\
\hline Quick Response Code & \\
\hline
\end{tabular}

How to cite this article:

B. Chandrakala, G. Sumathy, S.Kanimozhi, R.Sathish. (2017). Complete Type of Metopism in Adult Human Dry Skull - Anatomical Variation. Int. J. Curr. Res. Med. Sci. 3(10): 67-69.

DOI: http://dx.doi.org/10.22192/ijcrms.2017.03.10.011 